\title{
CONTRIBUTION AND INDEMNITY BETWEEN TORTFEASORS *
}

\section{Robert A. Leflar $\dagger$}

It is commonly said that the law has. a general rule refusing contribution and indemnity between joint tortfeasors. ${ }^{1}$ But a considerable number of exceptions to the so-called general rule are always stated, ${ }^{2}$ and it has been argued that the exceptions are so numerous that there can no longer be said to be any general rule denying contribution or indemnity, ${ }^{3}$ in fact, that the rule denying contribution is itself merely an exception to a general rule allowing contribution. 4 Actually, however, the rule of no contribution or indemnity is a broad one, applicable to many cases, closely related to and springing from the same roots as the numerous other rules in AngloAmerican law which find rough expression in the maxim ex turpi causa non oritur actio, ${ }^{5}$ and it is still alive and vigorous despite many attacks upon it. Merryzeather $v$. Nixan, ${ }^{8}$ the case generally credited with origin of the rule, does not by any means mark its limits, though it has been even quite recently contended that it does. ${ }^{7}$ In Merryzeather $v$. Nixan, the joint tortfeasors were intentional wrongdoers, but by the great weight of modern common law authority, contribution is denied also as between joint tortfeasors whose liability is based on negligence merely, as distinguished from intentional wrongdoing. ${ }^{8}$

The problems of contribution and indemnity, of course closely related, still present substantial differences. If contribution is to be allowed, a joint tortfeasor who has been compelled to discharge the whole obligation to the injured person will recover a ratable portion of such total amount from the other tortfeasor or tortfeasors, the idea being one of equalization of what

*The author acknowledges great indebtedness to Professors Warren A. Seavey and Edward S. Thurston of the faculty of the Harvard Law School for many and valuable suggestions received in the preparation of this paper.

$\dagger$ A. B., I922, University of Arkansas; LL. B., I927, S. J. D., 1932, Harvard University ; Professor of Law, University of Kansas Law School, on leave of absence from University of Arkansas Law School; member of the Arkansas bar; author of articles in various legal periodicals.

${ }^{1}$ Arnold, SURETyship ANd GUaranty (1927) 287; Burdick, Torts (4th ed. I926) 260; Clerk aNd LiNDSEII, TorTs (8th ed. 1929) 60; Pollock, TorTs (13th ed. 1929) 203; SaLMOND, TORTS ( 7 th ed. 1928) I03; I STREET, Foundation's of LEGAL Liability (I906) 490; 2 id., 240; THROCKMORTON's COOLEY ON TORTS (I930) I85; WOODWARD, QUASI CoNTRACTS (I913) 40I; KEENER, QUASI CONTRACTS (I893) 408. Also, see an excellent note, (I93I) 45 HARV. L. R. 349.

Supra note I.

3 Bailey v. Bussing, 28 Conn. 455 (I859) ; Reath, Contribution Between Persons Jointly Charged for Negligence-Merryweather v. Nixan (1898) i2 HARv. L. R. 176.

* 2 STREET, op. cit. supra note I, at $24 \mathrm{I}$; Reath, supra note 3.

- The companion maxim, in pari delicto potior est conditio possidentis, expresses another aspect of the same idea. See Broon's Legal Maxims (9th ed. I924) 462, 47I.

i 8 T. R. I86 (K. B. 1799).

'SAIMOND, TORTS I03.

${ }^{8}$ See infra notes 46 and 63 . 
should be a common burden. If indemnity be allowed, the one discharging the tort obligation is enabled to recover over the whole amount from the other, on the theory that as between them the primary liability was on the one against whom indemnity is given. As between tortfeasors, both contribution and indemnity have generally been limited to reimbursement for payments already made to the injured party, but it is possible in cases in which both or all tortfeasors are parties to the original action on the tort to require exoneration as between them provided this can be done without affecting adversely the interests of the injured party. In this paper, contribution between joint tortfeasors ${ }^{\circ}$ will be dealt with first, and indemnity will be taken up later.

\section{Contribution}

In a number of well known fields the law has manifested its unwillingness to come to the aid of persons whose conduct does not conform to legal standards, particularly if such persons, in order to make out a case, have to set up the non-conforming conduct as a part thereof. ${ }^{10}$ The legal logic used to defend this unwillingness to act may not be very satisfying to socially minded people; nevertheless, the law has preserved its "hands off" attitude. Among the conspicuous examples of this attitude are the illegal contract cases, in which the law will generally refuse all relief unless to one of the parties who is innocent or for some reason peculiarly deserving of protection, ${ }^{11}$ and the doctrine in equity that one seeking relief must come into court with clean hands. ${ }^{12}$ The doctrine of contributory negligence has been

"The term "joint tortfeasors" requires definition. In Paddock-Hawley Iron Co. v. Rice, et al., I79 Mo. 480,78 S. W. 634 (I904), it was held under a Missouri statute allowing contribution between joint tortfeasors that the term included only persons between whom there was intentional unity or concert of action, and excluded persons between whom there was only an unintended concurrence of activities producing one result. This definition was clearly changed by Kinloch Tel. Co. v. St. Louis, 268 Mo. 485 , I88 S. W. I82 (I9I6), holding (at 496, I88 S. W. at 184) that the statute "applies to a case of negligent omission of duty on the part of several tortfeasors which concurred in causing an injury, though there was no unity or concert of action on their part." The currently accepted definition of the term includes all cases where there is joint liability for a tort, whether the acts of those jointly liable were concerted, merely concurrent, or even successive in point of time. This definition has been followed under the statutes allowing contribution, see infra note 66 ; in jurisdictions allowing contribution at common law, Mitchell v. Raymond, I8I W is. 59I, I95 N. W. 855 (Ig23), and other cases cited infra notes 47, 48 and 49 ; and in the numerous cases denying contribution, see infra note 46 . On the question of joint liability and joinder of concurrent or successive tortfeasors as defendants in a single action, see CIARK, CODE PIEADING (I928) 266; and annotations (Ig20) A. L. R. 939; (Ig22) I6 A. L. R. 465; (1929) 62 A. L. R. I425.

${ }^{20}$ See Gilmore v. Fuller, Ig8 I1l. 130, 65 N. E. 84 (1902) ; cf. Coppedge v. Goetz Brewing Co., 67 Kans. 85I, 73 Pac. 908 (1903). And see the famous Highwaymen's Case, cited as Everet v. Williams in I LINDLEY, PARTNERSHIP (Ist ed., 1860 ) $16 \mathrm{r}$, note $g$, and in (1893) 9 L. Q. R. 197. The test of legal condemnation of the plaintiff's case, by which his right to recover is made to depend upon whether he is skillful enough to set up his claim without reference to its objectionable aspects, is generally deemed artificial and unfair. A test more directly dependent on the impropriety of the plaintiff's conduct is demanded. 3 WILtISTON, CONTRACTS (I920) §1753; WOODWARD, QUASI CONTRACTS \& I 43. 1.42 .

${ }^{11} 3$ WuLIston, Contracts $\$ \S 1631-32,1789-91$; WoOdWaRd, Quast Contracts $\$ \S 136$

12 I POMEROy, EQUTty JURTSPRUdence (4th ed. I918) 737. 
variously explained, ${ }^{13}$ but however it be explained it is in its operation clearly another manifestation of the law's unwillingness to aid persons whose conduct, here taking the form of neglectfulness, is deemed reprehensible, if this conduct has proximate causal connection with the very injury for which they seek reparation. Another less compact group of cases controlled by this same tendency of the law to withhold relief is that in which action is brought for a tort committed by one person upon another while both of them are engaged in some improper activity. For example, in Gilmore v. Fuller, ${ }^{14}$ the plaintiff and the defendant together were members of a gang engaging in a noisy and riotous charivari, in the course of which the defendant fired a gun negligently and wounded the plaintiff. Recovery was denied on the theory that relief would not be given for an injury arising out of the plaintiff's own wrongful activity. ${ }^{15}$

It seems that the rule refusing contribution between joint tortfeasors is rooted in this same unwillingness of courts to aid persons whose conduct has not measured up to legal standards. The reasons for the no contribution rule are substantially the same as the reasons for one of the related rules applied to a corresponding set of facts. This is particularly apparent when comparison is made of the operation of the no contribution rule in a negligence case, and the contributory negligence rule in a similar case. They reach identical results. Conversely, to allow contribution in a negligence case is in substance the same thing as substituting, a doctrine of comparative negligence such as is applied in admiralty cases ${ }^{16}$ for the doctrine of contributory negligence. ${ }^{17}$ In either case, the loss would be divided between the negligent parties, instead of being left to lie where it fell. It should be pointed out, however, that though support for the no contribution rule apparently must be drawn from the same substantive reasons that are sup-

${ }^{23}$ Bohlen, Contributory Negligence (1908) 2I HARv. L. REv. 233.

1* Supra note ro.

Is Accord: Wallace v. Cannon, $38 \mathrm{Ga}$. I99 (1868) (an interesting product of the Civil War); McLendon v. Harrell, 67 Ga. 440 (I88I); Harris v. Hatfield, 7r I11. 298 (1874); Frye v. Chicago B. \& Q. Ry., 73 Ill. 399 ( 1874); Jackson v. Lomas, 60 Mont. 8, I98 Pac. 434 (I92I); White v. Shawnee Milling Co., 94 Okla. 260, 22I Pac. IO29 (I923); Moore v. Woodson, 53 Tex. Civ. App. 588, I16 S. W. 608 (I909); Aldrich v. Harvey, 50 Vt. I6a (I877). But if the defendant intentionally inflicts upon the plaintiff an injury unconnected with the illegal enterprise in which they are jointly engaged, he will generally be held liable. Welch v. Wesson, 72 Mass. (6 Gray) 505 ( 1856 ). Also, an innocent person fraudulently induced to engage in the illegal enterprise is not barred. Panther v. MicKnight, I25 Okla. I34, 256 Pac. 916 (I926). An interesting study, too extended to be undertaken here, might consider the effect of the tortious act being connected, or unconnected, with the mutual wrongful enterprise; the effect of the mutual wrongful enterprise in the course of which the tort occurs being intentionally wrongful, or wrongful merely because negligent; and the effect of the tortious act being itself an intended act, or tortious merely because negligent.

${ }^{10}$ The Max Morris, 137 U. S. I, Ix Sup. Ct. 29 (I89a). See infra note 37.

${ }^{17}$ This fact is recognized in the cases allowing contribution. See Mitchell v. Raymond, supra note 9, at 600 , 195 N. W. at 859 , in which it was said, "Such an anomaly is often the resultant of the application of several rules of law." And see Note (I924) 22 MICH. L. REv. 831 . 
posed to support the doctrine of contributory negligence, ${ }^{18}$ there may be administrative reasons behind the latter doctrine that are irrelevant to the no contribution rule. For example, it may be feared that a sympathetic jury passing on a case controlled by a doctrine of comparative negligence might, in the absence of an exact top limit on recoveries, award damages for the entire injury to a negligent plaintiff, under the pretence that the total of damages incurred was some indefinite higher amount. This difficulty would not arise in a case in which contribution was being enforced between tortfeasors, because there the question of fact as to damages would be the very simple one of calculating an exact fraction of an already determined total of damages paid or payable to a third person.

The substantive reasons given for the unwillingness of courts to aid persons who were at fault in the transaction sued on may be summarized ${ }^{19}$ under two heads :

(I) Such non-access to the courts operates to punish for past misconduct, and by the same token to discourage other prospective improper activity of the same type. Thus it is argued that parties contemplating the execution of an illegal contract, knowing that the courts will neither enforce it nor compel any restitution of or reimbursement for the consideration given under it, however unevenly the burden of it may, at the end, be distributed between the parties to it, will for that reason be deterred from entering into it in the first place. Likewise it is contended that the contributory negligence rule induces people to be more careful to avoid impending injuries to their persons and property than they would be if the rule of comparative negligence were enforced. And it is urged that the rule of no contribution causes all prospective tortfeasors, whether they contemplate intentional or merely negligent wrongdoing, or even liability by respondeat superior, to guard themselves a little more warily against participation with others in acts which might produce liability in tort, because of a fear of being compelled to pay the entire damages instead of a ratable share of them only. ${ }^{20}$ An argument directly opposed to this would be entirely understandable. The fact that one joint tortfeasor may be held for the whole of the damages arising from the tort of course means that the other tortfeasors may go scot-free. This possibility of escaping all liability-a "sporting chance" of a type traditionally appealing to wrongdoers as a class-might cause many to be more willing rather than less willing to engage in the

${ }^{23}$ See Notes (1924) 22 Mich. L. REv. 83I; (I925) 34 Yale L. J. 427. Cf. Bohlen, stipra note 13 , at 242 .

${ }_{20}$ Cf. summary in Woopward, QUasI Contracts 213.

so "The reason why the law refuses its aid to enforce contribution amongst wrongdoers, is that they may be intimidated from committing the wrong, by the danger of each being made responsible for all the consequences." Thweatt's Adm'r. v. Jones, I Rand. 328 at 333 (Va. I823). See also Avery v. Central Bank, 221 Mo. 7I, 87, II9 S. W. I I06 (I909); Pjerson v. Thompson, I Edw. Ch. 212, 218 (N. Y. I83I); Andrews v. Murray \& Kane, 33 Barb. 354, 356 (N. Y. I86I) ; I COOLEY, TORTS (3d ed. I906) $26 \mathrm{I}$. 
wrongful activity. Even if the opposite be true, and the no contribution rule does have a deterrent effect, such an effect will in the nature of things apply only to persons who directly contemplate the commission of tortious acts. Where the joint activity was improper only because it was negligent, it would frequently be true that no expectation either of injury to another or liability to such other entered the minds of the joint tortfeasors. It is difficult to believe that the no contribution rule has ever had much effect by way of making careless people careful; that a motorist, for example, who cannot be deterred from negligence by fear of the physical consequences of a collision will be much affected in his conduct by the legal rule as to contribution between joint tortfeasors, assuming that he is acquainted with the rule. The truth of the matter seems to be that all along the courts have been assuming something which they did not know. They had the rule of no contribution between tortfeasors, and other related rules, and inasmuch as these rules would be "well supported in principle" if they served to deter people from participation in legally objectionable activity, the courts proceeded to assume that they did have this deterrent effect, without any actual proof whatever of the fact. On the other hand, there has been no proof that the rules do not have such a deterrent effect. It has merely been guessed that they do not. But this guess seems at least as intelligent as the old assumption otherwise, and perhaps a little more so. Possibly a study of the "law in action" could reveal the truth, but so far no such study has been made public. In the absence of such statistical information, it would seem wise to avoid broad assertions as to deterrent effect, and seek elsewhere for reasons for the no contribution rule and its fellows.

(2) The other reason given is that the courts have no time for, nor interest in, disputes about transactions which flout the very law which the courts are asked to administer. This sounds more like an epithet than a reason. It states a dislike for a certain type of litigation, but it does not say why such causes are not as deserving of decision as are any other kinds of suit. For centuries our common law courts have been taking on an increasing volume of work and wider areas of jurisdiction; the argument against overworking the courts, though frequently heard, is not commonly thought to be of sufficient weight to bar substantial causes from adjudication. And it is submitted that, apart from the supposed deterrent and punitive effect discussed in the last paragraph, the only social interest served by giving vent to the dislike for such litigants and their causes is a saving of the judicial time and energy which would be expended in trying them.

Before the joint tortfeasor cases are analyzed in detail, the nature of the remedy of contribution and the reasons for it should be examined. The remedy had its origin in equity, but has long since been accepted at law 
also, ${ }^{21}$ though there have been minor variations between its equitable and legal forms. ${ }^{22}$ The most common case for contribution has been between sureties on the obligation of another, and courts have said that the right to contribution as between such sureties is contractual in nature, the theory being that each surety on entering into the obligation agrees with every other surety to contribute his share to whatever burden falls upon any of them. ${ }^{23}$ It is not of course contended by anyone that such an affirmative consensual arrangement between the parties actually occurs; it is merely assumed that they, tacitly, have accepted the rights and duties which the law, for other reasons, has seen fit to assign them. These other reasons are what is important. They can best be discovered from cases to which the confusing language of implication of contract is least applicable. Incidentally, such cases are more comparable than others to the joint tortfeasor situation.

It is well settled that contribution between sureties on the same obligation will be enforced even though they became sureties by entirely separate undertakings at different times, and even unknown to each other. ${ }^{24}$ It is not so well settled, but the decided weight of recent authority holds, that where several principals have independently placed property in the hands of one agent who validly, though without authority, pledges all the property to another as security for the agent's own debt, some but not all of the property being taken by the pledgee in payment of the debt, the remaining property must be shared proportionately by all the principals. ${ }^{25}$ This is true

2 There are some early reports of contribution allowed "by the custom of the city" where cases arose in large trading centers. Offley v. Johnson, 2 Leon. I66, p. 202 (K. B. I584) ; Layer v. Nelson, I Vern. 456 (Ch. I687). Contribution was enforced as an equitable doctrine almost as early, however, Fleetwood v. Charnock, Nels. Io (Ch. I629); and was not formally taken over by the law courts for many years. See ARANT, SURETYSHIP (I93I) 334; ARNoLD, op. cit. supra note I, at 262; KEENER, QUASI CONTRACTS (I893) 400; SPENCER, SURETYSHIP (I9I3) 200; StEarNS, SURETYSHIP (3d ed. 1922) 473; WOODWARD, QUASI CONTRACTS 398; Anon., The Law of Contribution (I869) 8 AM. L. REG. (N. S.) 449. For a review of the English cases, see Wolmershausen v. Gullick [I893] 2 Ch. 5I4.

CIn law the amount of the contributive shares was determined by the total number of persons originally liable to contribute, while in equity it was determined by the number of contributors who were solvent and in the jurisdiction. Some cases at law held that the liability to contribute did not survive against the estate of a decedent; equity allowed such survival. There were other similar differences. In modern practice they have tended to disappear, the equity rules being generally adopted by law. ARANT, SURETYSHIP 335; ARNOLD, op. cit. supra note $\mathrm{I}$, at 264 .

${ }^{3}$ Batard v. Hawes, 2 E. \& B. 287 (Q. B. 1853); Chipman v. Morrill, 20 Cal. I30 (1862); Johnson v. Harvey, 84 N. Y. 363 (1881). See KEENER, QUASI ContRAcTs 401 ; WOODWARD, QUASI CONTRACTS 399.

" Deering v. Earl of Winchelsea, 2 Bos. \& P. 270 (C. P. 1787) ; United States Fid. \& Guar. Co. v. Naylor, 237 Fed. 314 (C. C. A. 8th, Ig16); Warner v. Morrison, 3 Allen 566 (Mass. 1862) ; Young v. Shunk, 30 Minn. 503, 16 N. W. 402 (1883). See ARNold, op. cit. supra note 1 , at $268 ; 2$ WIILISTON, CoNTracts 2316; WoOdWARD, QUASI CoNTRACTS 401 ; Note (1932) 76 A. L. R. 904.

ss In re Toole, 274 Fed. 337 (C. C. A. 2d, 1921); McBride v. Potter-Lovell Co., 169 Mass. 7, 47 N. E. 242 (1897); Vian v. Hilberg, III Neb. 232, 196 N. W. 153 (I923); Asylum of St. Vincent de Paul v. McGuire, 239 N. Y. 375, I46 N. E. 632 (I925); Vance Lumber Co. v. Fraser, I62 Wash. 347, 298 Pac. 438 (I93I). Contra: In re McIntyre, I89 Fed. 46 (C. C. A. 2d, IgII); Johnson v. Bixby, 252 Fed. I03 (C. C. A. 8th, I9IS). And see Holahan, Contribution Among Securities Pledged by a Defaulting Stock Broker (1930) 4 So. CALIF. L. R. I; Note (I925) 35 Yale L. J. 92 ; Note (Ig25) 38 A. L. R. I2I9. 
even though the property not taken is definitely identifiable as that of a single principal. Nothing in the nature of a contract for contribution can be spelled out in these cases, yet contribution is enforced. Likewise, if one tenant in common makes necessary repairs on the commonly owned property or pays obligations resting upon it, he may demand contribution from the other tenants in common. ${ }^{26}$ Corporate stockholders held under statutes creating personal liability in them for debts of the corporation can compel contribution from stockholders whose statutory liability was not directly enforced. ${ }^{2 \tau}$

The central feature of all these cases, as well as of the cases in which contribution between joint tortfeasors is enforced, is the fact of common liability for an obligation resting at law equally upon the property or persons between whom there is contribution. The reasoning of the decisions and of the commentators thereupon constantly falls back upon that fact, though the forms of language used in referring to it are various. The maxin "Equality is equity" appears probably in half the cases, whether in law or equity. ${ }^{28}$ Some are satisfied with the statement that the doctrine rests upon "the general principles of justice and equity" 29 or upon "the broad principles of natural justice". ${ }^{30}$ The more recent cases and writers nearly always say expressly that the fact of common obligation is the important thing. "The reason . . . is because by such payment he has relieved them of a common burden and hence they ought to reimburse him for their proportionate part of his loss." 31 "Equality of burden as well as of the benefits is the basis for its recognition." 32 The term "unjust enrichment" seldom, if ever, appears in the cases, but it seems obvious that the results of the cases, and the reasons given for them, really fall within the area to which writers on quasi contracts have given that name. The idea emphasized is that each obligor should bear his part of the burden; and if one discharges the burden of another, without being reimbursed, the other has gained a financial advantage to which he is not equitably entitled. That is merely another way of saying that the other would be unjustly enriched at the

${ }^{\mathfrak{s}}$ Campbell v. Mesier, 4 Johns. Ch. 332 (N. Y. 1820) (repairs to party wall); Cocks v. Simmons, 55 Ark. I04, I7 S. W. 594 (I891) (taxes). See I TmFanY, REaI ProperTY (2d ed. 1920) 687; The Law of Contribution, supra note 2I, at 456.

${ }^{27}$ Wolters v. Henningsan, II4 Cal. 433, 46 Pac. 277 (I896) ; Umsted v. Buskirk, I7 Ohio St. 113 (1866). See Lex v. Selway Steel Corp., 203 Iowa 792, 206 N. W. 586 (rg25); StEarNs, SuRETyship 483.

${ }^{23}$ Quotation of this and other equitable principles in contribution cases on the law side is attributable to the fact that law courts freely recognize the equitable origin and nature of the remedy of contribution.

${ }^{\infty}$ SPENCER, SURETYSHIP 200.

30 Mitchell's Adm'r v. Sproul, 5 J. J. Marshall 264 at 270 (Ky. I83I), quoted in ARnoLd, op. cit. supra note $\mathrm{I}$, at 263 .

al 2 Willistón, Contracts 23 i7.

$\approx$ Arnold, op. cit. supra note I, at 270. See also Note (1925) 35 YALE L. J. 92, 94: "any situation involving a common obligation." 
expense of the one who paid off the common obligation. ${ }^{\text {s3 }}$ Actually, it seems not to make much difference what formal explanation is accepted, so long as it is understood that the right to contribution is not necessarily based on a voluntary consensual transaction between the parties. The essential thing is the attempt to be fair as between persons subjected to a common legal liability. ${ }^{34}$

There are also social considerations favoring the allowance of contribution between persons who are under a liability that is joint and several in nature. Foremost among these is the fact that a corrupting influence tends to manifest itself in cases where contribution is not allowed. If those subject to a common liability know that the whole obligation will have to be discharged by those against whom the creditor chooses to enforce his claim, and that the others will escape liability altogether, frequent attempts to influence creditors in their selection of the unfortunate defendants will be inevitable. ${ }^{35}$ Direct bribery in the form of payments which the creditor would receive over and above the total amount of his enforceable claim can easily be understood in such cases, and other less tangible but equally effective benefits and favoritisms could scarcely be avoided. There may be differences of opinion as to the significance of such corruption, but its reality as a result of the no contribution rule cannot be denied. Another social consideration should be presented as worthy of careful thought. At least some private liabilities are imposed partly because they serve as agencies for social control over the persons upon whom they are imposed, inducing such persons to observe social obligations to their fellows. Known opportunities to escape these liabilities, either by chance or collusion, may

23 This fact has been pointed out by those who have approached the topic from the point of view of the law of quasi contracts. ". . . the liability of the defendant rests upon the nrinciple that there would be an unjust enrichment on his part were he not compelled to share in a burden which should have been borne by him as well as by the plaintiff." KeENer, QUASI Contracts 406. Also see Note (I925) 35 Y ALE L. J. 92, 98, referring to cases such as those cited in note 25 supra: "The resulting increase in the value of the property interest of those depositors whose securities have survived constitutes an unjust enrichment which requires contribution to those at whose expense it was created." $C$. WOODWARD, QUASI CONTRACTS 40I, where the position is taken that, though the right to contribution is properly explainable on principles of unjust enrichment, the tendency of law courts to speak of it as contractual has so confused the issue that it is difficult to say definitely what is its underlying basis. It is submitted, however, that the total absence of anything in the nature of a consensual arrangement in many of the cases in which contribution is enforced renders the contract explanation so artificial that it is not entitled to serious consideration.

${ }^{34}$ It has been pointed out that much of the common law which jurists in the last century tried to explain in terms of contract or voluntary undertaking is really based upon rules laid down by the law-making power without regard to the will of particular parties to litigation, such rules being laid down on the theory that they achieved fair and socially desirable results between litigants occupying somewhat standardized relational positions. See Pound, SpIRTt of the Comimon LAW (Ig2I) 20-3I. Also see ARnold, op. cit. supra note I, at 27I: "The relation of the parties must determine the right to demand contribution."

${ }^{3 s}$ For cases of such collusion between a tort plaintiff and one of several joint tortfeasors, see infra note 52. Compare cases cited in note 53. It is common knowledge that such undercover dealings occur constantly in personal injury cases involving joint tortfeasors, though affirmative record of them seldom appears in the reported decisions. 
materially lessen their effectiveness as agencies for social control. A rule of no contribution between persons subject to a common liability does afford such an opportunity for escape. ${ }^{36}$

All these considerations seem as applicable to the problem of contribution between tortfeasors as to contribution between other classes of persons subject to a common liability. As between the tortfeasors themselves, their fault or lack of fault being in the eyes of the law approximately equal, the fairness of contribution need not be argued. The theory of unjust enrichment fits the facts of the tortfeasor case as well as it fits those of any contribution case. One person has discharged a burden which both in law and conscience was equally the liability of another; if contribution be not allowed, the net assets of the other will be increased at the expense of the one. If it be urged that there is no particular advantage to society in preventing this, on the theory that all social interests are cared for adequately when the injured person has recovered from any or all tortfeasors, and that the dispute between the tortfeasors is their own private concern purely, two answers may be given. First, the dispute between the tortfeasors is no more purely their private concern than is that between co-sureties, one of whom has discharged the whole suretyship obligation, nor than that between any of the others between whom the law enforces contribution. In all these cases purely private claims are presented for adjudication. But the enforcement of private claims is the main business of the judicial system. And, secondly, the point is based on a wholly mistaken assumption. Very substantial social interests which are served by enforcing contribution were pointed out in the paragraph next before this.

In admiralty, the courts have felt free to develop their own rules uncontrolled by the common law decisions, with the result that they never accepted either the doctrine of contributory negligence or the rule of no contribution between negligent joint tortfeasors. Instead of the doctrine of contributory negligence they adopted a system under which the injured party and the injuring party, both negligent, are required to divide the total loss between themselves equally. ${ }^{37}$ Consistently, the admiralty courts have

${ }^{20}$ A line of reasoning directly opposed to this has been taken to support the rule denying contribution between joint tortfeasors. See supra note 20 , and accompanying text.

${ }^{3}$ The Max Morris, supra note 16; The Eugene F. Moran, 212 U. S. 466, 29 Sup. Ct. 339 (Ig09); Wood Towing Corp. v. Tomasos, 25 F. (2d) 395 (C. C. A. 4th, I928). It has been held in personal injury cases in admiralty that the loss need not be divided equally, but may be apportioned according to fault. The Lackawanna, I5I Fed. 499 (S. D. N. Y. I907), noted in (I907) 7 CoL. L. Rev. 352. See HugBES, ADMrRAlTY (2d ed. I920) 22I. Other maritime nations have adopted this rule for collisions also, but in American courts an equal division is insisted upon, even though the parties were in unequal fault. The Margaret, 30 F. (2d) 923 (C. C. A. 3d, I929); certiorari denied, Bull S. S. Co. v. Hudson, 279 U. S. 862, 49 Sup. Ct. 479 (1929). See Huger, The Proportional Damage Rule in Collisions at Sea (1928) 13 Cops. L. Q. 531 ; Sprague, Divided Damages (1928) 6 N. Y. U. L. REv. 15; Robinson, Legal Adjustments of Personal Injury in the Maritime Induistry (I930) 44 HARv. L. REv. 223, 235. The doctrine of comparative negligence has been enunciated, perhaps carelessly, in some common law courts. See Galena Ry. Co. v. Jacobs, 20 
also refused to follow the no contribution rule in negligence cases. ${ }^{38}$ It has never been suggested that the rule in admiralty operates to induce more collisions or other negligent injuries than occur under the common law rules of contributory negligence and no contribution, or that it is substantially more difficult to administer. ${ }^{39}$

There has been a great deal of direct criticism of the common law rule denying contribution between tortfeasors, ${ }^{40}$ but practically all of it has been against the rule as applied in negligence cases. Critics have apparently been content to let the no contribution rule run its course where intentional tortfeasors are involved. It is easy to understand how the two supposed reasons for the rule have been assumed to be more logically applicable to intentional wrongdoers than to persons merely negligent, yet it is true that there is absolutely no factual proof that the rule operates effectively as punishment and discouragement to wrongdoers, or that the law's attitude of dignified aloofness serves any good purpose whatever, whether the would-be litigant be a double-dyed villain, or only an ordinary imprudent man. Be that as it may, the common law is settled, and there seems no demand for a change -there can be no non-contractual contribution between tortfeasors who knew and intended the tortious consequences of their misconduct. ${ }^{41}$ Some

III. 478 at 496 (1858). And it has been adopted in a number of federal and state statutes designed to cope with special situations, such as Employer's Liability. THROckMorTon's COOLEY on ToRts 644. For example see 35 STAT. 66 (IgO8), 45 U. S. C. A. \$ 53 (I928). These statutes often provide for apportionment of damages according to fault, rather than equal division of damages. For an extended study of the problem, see Mole \& Wilson, A Study of Comparative Negligence (I932) If ConN. L. Q. 333, 604.

$\approx$ The Alabama v. The Gamecock, 92 U. S. 695 (I875); Erie R. R. Co. v. Erie Transp. Co., 204 U. S. 220, 27 Sup. Ct. 246 (1907); Great Lakes Towing Co. v. Masaba S. S. Co., 237 Fed. 577 (C. C. A. 6th, Igr6); New York \& Porto Rico S. S. Co. v. Lee's Lighters, 48 F. (2d) 372 (E. D. N. Y. I930).

"Admiralty courts act without juries, the fact-finding agency being the judge himself, sometimes aided by appointed commissioners. See I BENEDICT, AdMIRALTY (5th ed. 1925) \$405; Hugres, ADMIRALTY 410. Possibly this makes for a simpler and surer administration of a doctrine of comparative negligence than would be possible in a court sitting with a jury as the fact-finding body. It is suggested in the article by Mole \& Wilson, supra note 37 , that this should not be assumed, however. At any rate the point would not be very important in contribution cases, since the most troublesome fact question involved in comparative negligence cases, that of assigning a proper amount of loss to be borne by each party, would in contribution cases be quite simple. It would be determined by calculating an exact fraction of an already determined total of damages. See supra note 18 , and accompanying text.

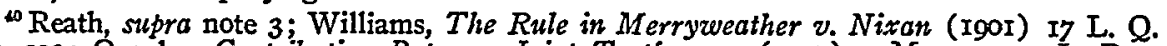
REv. 293; Quarles, Contribution Between Joint Tortfeasors (IgI7) I MARQUETTE L. REV. I4I; Brown, Contribution Between Joint Wrongdoers (I917) 85 CENT. L. J. 244 ; Gregory, Vicarious Responsibility and Contributory Negligence (I932) $4 \mathrm{I}$ Y $\mathrm{ALE}$ L. J. 83I, 845; Notes (I92I) 30 YALE L. J. 527; (1924) 22 MICH. L. REV. 831; (I928) 27 MICH. L. REV. IIO; (I929) 27 MrCh. L. Rev. 478; (I928) 76 U. of PA. L. REv. 979; (I930) 34 DiCK. L. Rev. I23; (I930) I8 CAIIF. L. Rev. 522; (I93I) I6 MINN. L. Rev. 73; (I932) 32 CoL L. REv. G4; and an especially well prepared note in (I93I) 45 HARv. L. REv. 349. Cf. Notes (s914) I VA. L. REv. 313; (1925) 34 Y ALE L. J. 427, reprinted in (I925) 42 So. AFr. L. J. I84; (I93I) 5 CIN. L. REv. 339.

- Merryweather v. Nixan, supra note 6, at 186; Weld-Blundell v. Stephens, [1920] A. C. 956; Rucker: v. Allendorph, 102 Kans. 771, I72 Pac. 524 (1918); Alexander y. Alexander, I54 Ky. 324, 157 S. W. 377 (19r3); Johnson v. Torpy, 35 Neb. 604, 53 N. W. 575 (I892); s. c.\$ 43 Neb. 882,62 N. W. 253 (1895); Peck v. Ellis, 2 Johns.'Ch. 
statutes ${ }^{42}$ contain language broad enough to permit contribution between such intentional wrongdoers, but it is possible that even these statutes will be restricted by interpretation to exclude such cases.

In sharp contrast with the cases just mentioned is another group in which contribution has apparently always been permissible-cases in which two or more persons intentionally do an act which, by reason of their nonnegligent mistake of fact, they in good faith believe to be proper and lawful, the act in fact being tortious as to third parties. Most of the cases in this group involve attachments levied upon property which later turned out to be exempt from attachment or owned by someone other than the judgment debtor, thus subjecting the attaching creditors to tort actions for wrongful levy of attachment. ${ }^{43}$ In such cases, contribution between the wrongful attaching creditors is permitted, and it is generally deemed immaterial whether the attaching creditors acted in concert, or levied independently on the same property. ${ }^{44}$ It has not been suggested that possible negligence of one or both tortfeasors in not learning of the facts which rendered their acts tortious would affect the holding as to contribution. The two reasons adduced for the rule denying contribution may well have been imagined to be less applicable to this type of case than to cases of intended wrongdoing, but there is no proof save in supposition that the respective holdings as to contribution affect either class of tortfeasors one way or another. They represent the common law as it now stands; that is all that can be said of them..$^{45}$

The situation is not materially different where the tort liability of the parties between whom contribution is sought is based on personal negligence as distinguished from intended acts. The great weight of modern authority,

I31 (N. Y. I816) ; Davis v. Gelhaus, 44 Ohio St. 69, 4 N. E. 593 (I886) ; Fakes v. Price, I8 Okla. 4I3, 89 Pac. II23 (I907); Boyer v. Bolender, I29 Pa. 324, I8 Atl. I27 (I889); National Surety Co. v. Massachusetts Bonding \& Ins. Co., I9 F. (2d) 448 (C. C. A. 2d, I927) ; Ladd v. Ney, 36 Tex. Civ. App. 20I, 8I S. W. 1007 (I904); Turner v. Kirkwood, $49 \mathrm{~F}$. (2d) 590 (C. C. A. roth, I93I). It has also been suggested that persons whose tort lialility is based on violation of a statute, irrespective of whether they knew they were violating the statute or even knew of the statute's existence, are tarred black with the same brush as are intentional wrongdoers, and can never get contribution. Nettles v. Alexander, I69 Ark. 380, 275 S. W. 708 (I925); Fidelity \& Casualty Co. of N. Y. v. Christenson, I83 Minn. 182, 236 N. W. 618 (I93I). See discussion of this point, infra note 64.

"Discussed infra note 66.

${ }^{23}$ Vandiver v. Pollak, 97 Ala. 467 , 12 So. 473 (I893); s. c., I07 Ala. 547, I9 So. 180 (I894); Farwell v. Becker, I29 IIl. 26I, 21 N. E. 792 (I889); Selz, Schwab \& Co. v. Guthman, 62 Ill. App. 624 (I896) ; First Natl. Bk. v. Avery, 69 Neb. 329,95 N. W. 622 (I903). See also Acheson v. Miller, 2 Ohio St. 203 (1853), containing an oft-quoted dictum.

"Several of the cases cited in note 43 involved the latter set of facts. A contrary holding which seems not to have been followed elsewhere appears in Paddock-Hawley Iron Co. v. Rice, supra note 9 .

is See also Central Bk. \& Trust Co. v. Cohn, I50 Tenn. 375, 264 S. W. 64 I (1924), in which successive innocent converters of a promissory note were held entitled to contribution among themselves; Thweatt's Adm'r v. Jones, supra note 20; Jacobs v. Pollard, to Cush. 287 (Mass. I852) ; Eureka Coal Co. v. Louisville \& N. Ry. Co., 2 I9 Ala. 286, I22 So. 109 (1929). 
where it is unchanged by statute, denies any right to contribution. ${ }^{46}$ But contribution between negligent joint tortfeasors has been declared proper, without the aid of statute, by the courts of at least three states-Wisconsin, ${ }^{47}$ Pennsylvania ${ }^{48}$ and Minnesota, ${ }^{48}$ and perhaps a fourth, Oregon, ${ }^{50}$ and the House of Lords permits it in negligence cases arising from Scotland. ${ }^{51}$ These courts have for the most part been moved by the obvious injustice, as between the two tortfeasors, of one bearing the whole loss while the other goes free, when in fact one is neither more blameworthy nor more free of blame than the other, the incidence of the burden being determined by the accident of the recovering plaintiff's levy of execution, or even by collusion between the recovering plaintiff and one of the defendants. ${ }^{52}$ Close analysis of the nature of the right to get contribution is not found in the cases. They simply emphasize the equities apparent on the face of the facts. Probably that is enough. A formulation of underlying principles in terms of unjust enrichment can do little more.

It has also been held, in a jurisdiction not permitting contribution, that one of two defendants against whom a tort judgment has been rendered jointly could pay off the judgment through a straw man, take assignment thereof in the name of the latter, and then enforce contribution from the other defendant. ${ }^{53}$ Such a decision indicates a certain lack of sympathy for the no contribution rule, even when the court is technically required to enforce it. A similar situation arises when, as is very often the case in

${ }^{16}$ Gulf \& S. I. R. R. Co. v. Gulf Ref. Co., 260 Fed. 262 (S. D. Miss., rgrg) ; Forsythe v. Los Angeles Ry. Co., I49 Cal. 569, 87 Pac. 24 (I906) ; Central of Ga. Ry. Co. v. Swift \& Co., 23 Ga. App. 346, g8 S. E. 256 (Ig18); City of Louisville v. Louisville Ry. Co., I56 Ky. 14I, 160 S. W. 771 (1913) ; Larkin Co. v. Terminal Warehouse Co., I6I App. Div. 262, 146 N. Y. Supp. 380 (I914); aff'd, 22I N. Y. 707,117 N. E. I074 (I9I7); Cain v. Quannah Lt. \& Ice Co., I3I Okla. 25, 267 Pac. 64I (1928) ; Spalding v. Administrator of Oakes, $42 \mathrm{Vt}$. 343 (1869); and cases cited infra note 63. Also see Thweatt's Adn'r v. Jones, supra note 20. The cases cited are merely typical ones, and do not by any means comprise an exhaustive list. There are literally hundreds of American cases to this effect. Most of the cases involve attempts to secure indemnity as well as contribution.

"Ellis v. Chicago \& N. W. Ry. Co., I67 Wis. 392, I67 N. W. I048 (1918); Mitchell v. Raymond, supra note 9; Sattler v. Neiderkorn, I90 Wis. 464, 209 N. W. 607 (I926); Wait v. Pierce, I9I Wis. 202, 210 N. W. 822 (I926); Roeber v. Pandl, 200 Wis. 420,228 N. W. 512 (1930); Haines v. Duffy, 206 Wis. I93, 240 N. W. I52 (193I).

"Armstrong County v. Clarion County, $66 \mathrm{~Pa}$. 218 (1870); Goldman v. Mitchell-Fletcher Co., 292 Pa. 354, I4I Atl. 23I (I928).

${ }^{20}$ Underwriters at Iloyd's, etc. v. Smith, 166 Minn. 388, 208 N. W. I3 (I926); Duluth, M. \& N. Ry. v. McCarthy, 183 Minn. 4I4, 236 N. W. 766 (I93I).

${ }^{50}$ See Furbeck v. I. Gevurtz \& Son, 72 Ore. I2, 22, I43 Pac. 654 (I914).

ni Palmer v. Wick \& Pulteneytown Ship. Co., Ltd. [I894] A. C. 3 I8.

${ }^{62}$ For a strikingly successful case of such collusion see Pennsylvania Co. v. Western Penn. Rys. Co., 110 Ohio St. 516, 144 N. E. 51 (rg24). Also see Norfolk S. Ry. Co. v. Beskin, 140 Va. 744, 125 S. E. 678 (I924).

${ }^{20}$ Gale Lumber Co. v. Bush, 227 Mass. 203, II6 N. E. 480 (I9I7), the court saying: "A motive to use legal means to make joint tortfeasors contribute to a payment of damages flowing from a wrong in which they have participated contravenes no policy of the law." This attitude is not general, however. Most courts denying contribution would do so despite the intervention of a strawman. Lillie v. Dennert, 232 Fed. 104 (C. C. A. 6th, 1916): Manowitz v. Kanov, I07 N. J. L. 523. I54 At1. 621 (I93I). See Note (I93I) 75
A. L. R. I468. 
modern times, one of the joint tortfeasors is represented by a casualty insurance company or a surety on an appeal bond who pays off the entire judgment and then seeks contribution of ratable shares from the other tortfeasors and their insurers or sureties. On these facts, the New York courts, while denying contribution between the tortfeasors themselves, decided that a surety occupied a different position, was not tarred with the black of the principal's wrongdoing, and would be subrogated, as purchaser of the judgment, to the original judgment creditor's rights. ${ }^{54}$ Most jurisdictions, however, have taken the opposite view, and have treated the insurer or surety exactly the same as his principal. This has been done both in jurisdictions which deny contribution between the tortfeasors themselves ${ }^{55}$ and those in which contribution is allowed. ${ }^{56}$ It is scarcely possible to imagine how the no contribution rule applied between casualty insurance companies will deter any prospective joint tortfeasors from their misconduct. There may be some valid question, however, as to whether such sureties should be given greater rights than their principals enjoy; ${ }^{5 T}$ such partial, palliative relief might postpone indefinitely the more complete relief which must take the form of abandonment of the no contribution rule altogether.

Closely related to the cases referred to in the last paragraph are those in which two or more persons are liable by respondeat superior for the acts of a joint employee or representative. Contribution between the persons thus subjected to liability without fault has generally been permitted. ${ }^{58}$ It would seem that the holding must necessarily be the same where two or more persons, as joint owners or occupiers of property, are subjected to an absolute liability without fault under the doctrine of Rylands $v$. Fletcher ${ }^{59}$

s Kolb v. National Surety Co., I76 N. Y. 233, 68 N. E. 247 (I903) ; City of White Plains v. Ellis, II3 Misc. 5, I84 N. Y. Supp. 444 (1920). New, York has since by statute changed its law, and permits contribution between joint tortfeasors. See infra note 66.

${ }^{\circ}$ Adams v. White Bus Line, I84 Cal. 710, I95 Pac. 389 (I92I) (cf. Salter v. Lombardi, Ir6 Cal. App. 9r1, 3 P. (2d) 38 (193I)); United States Cas. Co. v. Cincinnati, N. O. \& T. P. Ry. Co., 218 Ky. 455, 291 S. W. 709 (I927) ; Fiorentino v. Adkins, 9 N. J. Misc. 446 , I54 Atl. 429 (I93I); Royal Indem. Co. v. Becker, I22 Ohio St. 582, I73 N. E. I94 (I930); Cain v. Quannah It. \& Ice Co., supra note 46. Also see National Surety Co. v. Massachusetts Bonding \& Ins. Co., supra note 4I (intentional wrongdoers); Note (I93I) 75 A. L. R. 1486 .

${ }^{80}$ Underwriters at Lloyd's, etc. v. Smith, supra note 49; Goldman v. Mitchell-Fletcher Co., supra note 48 . See also Fidelity \& Casualty Co. of N. Y. v. Christenson, supra note 4I (contribution denied for special reasons); Boyer v. Bolender, supra note 4I (contribution denied because wrongdoing intentional rather than negligent).

"See Note (192I) 5 Minn. L. Rev. 370. Cf. (I93I) 79 U. of PA. L. Rev. 507.

\$ Wooley v. Batte, 2 C. \& P. 4I7 (I826); Bailey v. Bussing, supra note 3 ; Farney v. Hauser, I09 Kan. 75, I98 Pac. I78 (I92I); Hobbs v. Hurley, II7 Me. 449, I04 At1. 8I5 (I9I8); Ankenny v. Moffett, 37 Minn. I09, 33 N. W. 320 (1887) ; Horbach's Adm'r v. Elder, I8 Pa. 33 (I85I). Contra: Pearson v. Skelton, I M. \& W. 504 (Ex. I836) (but here there was a partnership fund out of which losses were expressly payable); Curtis v. Welker, 54 App. D. C. 272, 296 Fed. IOIg (rg24). Cf. Smith v. Ayrault, 7 I Mich. 475, 39 N. W. 724 (I888).

${ }^{\circ}$ L. R. 3 H. L. 330 (I868) ; also, see Bohlen, Rule in Rylands v. Fletcher (IgII) 59

U. OF PA. L. REv. 298, 373, 423 . 
for injuries arising from the dangerous nature of the property. This conclusion at least receives some support from one decision. ${ }^{60}$ In neither case is there anything in the nature of intentional wrongdoing or even negligence on the part of the so-called joint tortfeasors between whom contribution is sought, and their original liabilities were equally based on a single mutual relationship to the person or thing actually producing the harm to third parties.

It is difficult to see any essential difference between the cases just dealt with and those in which contribution is sought between previously unconnected principals liable under the rule of respondeat superior for injuries produced by the concurrent but not concerted acts of their respective agents. If complete absence of any wrongdoing state of mind in the persons jointly liable for the tort were the test, contribution would be permitted between such principals. The fact that they did not, through their agents, act in concert, but rather by independent operations which happened to take effect at the same time and place, has not kept the law from treating them as joint tortfeasors. They are jointly and severally liable to injured persons, just as much as if their agents had acted in concert, and they are subjected to all the other rules of law applied to joint tortfeasors. ${ }^{61}$ No difference lies in that quarter. Yet no case has been found in which it is even suggested that separate principals of independently wrongdoing agents should be subject to contribution the same as joint principals for a single wrongdoing agent, or be treated in any respect otherwise than as personally wrongdoing tortfeasors are treated. ${ }^{62}$ This fact clearly indicates that after the no contribution rule made its beginning in the law it developed without much regard for the so-called reasons that have been enunciated in support of it. It cannot reasonably be argued, much less proved, that the no contribution rule has any deterrent effect at all upon principals whose tort liability exists by respondeat superior alone, and judicial distaste for the type of claim presented seems altogether unreasonable. Yet in modern practice such litigants are plaintiffs in a very large proportion of the tort cases in which contribution is or might be asked for, and in nearly all common law states contribution is denied them. ${ }^{63}$

${ }^{\infty}$ Ankeny v. Moffett, supra note 58.

a Supra note 9.

C2 This possibility is suggested in a note in (I930) 34 DICK. L. REV. 123 as an explanation of the case of Goldman v. Mitchell-Fletcher Co., supra note 48 , but that case actually went on the broader ground that contribution between negligent tortfeasors was permissible.

* Linion Stockyards of Omaha v. Chicago, B. \& Q. R. R. Co., Ig6 U. S. 2I7, 25 Sup. Ct. 226 (1905); Central of Ga. Ry. Co. v. Macon Ry. \& Lt. Co., 9 Ga. App. 628, 71 S. E. I076 (I9II); Illinois C. R. R. Co. v. Louisville Bridge Co., I7I Ky. 445 , I88 S. W. 476 (I9I6); Detroit Ry. Co. v. Boomer, I94 Mich. 52, I60 N. W. 542 (1916) ; Public Serv. Ry. Co. v. Mateucci, IO5 N. J. L. II4, I43 Atl. 22I (I928); rev'd 6 N. J. Misc. 34, I40 At1. 442 (I928); Taylor v. Jones Constr. Co., 195 N. C. 30, I4I S. E. 492 (I928) ; Norfolk So. Ry. Co. v. Beskin, supra note 52; Alaska Pac. S. S. Co. v. Sperry Flour Co., 107 Wash. 545, I82 Pac. 634, I85 Pac. 583 (I919); s. c., I22 Wash. 642, 211 Pac. 761 (1922). 
In the few states permitting contribution as a common law matter, the right has apparently been limited to cases in which there was no intentional commission of tort. By way of extension of this limitation it has been decided that if a tortfeasor's misconduct took the form of violation of a statute, he will be barred from the right to contribution given to negligent tortfeasors, even though the violated statute was one that purported to do no more than set up a standard of conduct for traffic safety. ${ }^{84}$ Most of such enactments are intended to set up statutory standards of due care under the specified circumstances, concrete rules as to what amounts to negligence. Violations will as often be the result of inadvertence as of deliberate choice. One who violates these statutes and in doing so causes injury to another is usually deemed guilty of negligence only; he is not treated as an intentional tortfeasor. In most American states today such statutes control almost every aspect of the process of driving an automobile along a public highway. Probably a large percentage of the cases in which contribution has been allowed between negligent tortfeasors ${ }^{65}$ were cases in which some violation of statute was included in the negligence charged against them, without any suggestion that it made any difference as far as the right to contribution was concerned. It would seem unfortunate to eliminate all possibility of contribution in such a considerable body of torts cases.

One fourth of the American states have shown their distaste for the no contribution rule by enacting statutes, for the most part in recent years, eliminating the old rule in whole or in part. ${ }^{66}$ It is to be feared, however,

- Fidelity \& Casualty Co. of N. Y. v. Christenson, supra note 4I (roadside parking at night without taillight burning), noted in (I932) 30 MrCH. L. REv. 804; (1932) 27 ILI. L. REv. 78. Also see Nettles v. Alexander, supra note $4 \mathrm{r}$.

« Supra notes 47,48 and 49 .

${ }^{6 B}$ Twelve states have statutes under which contribution between joint torfeasors is permitted to varying extents and under differing circumstances. The statutes in nine states are fairly broad, allowing contribution in most negligence cases under usual procedural conditions. Ky. STAT. (Carroll, I930) \$ 484a (enacted in 1926); MD. ANN. Cone (Bagby, Supp. I929) art. 50, \$ Iza (enacted in I927); Mo. REv. STAT. (I929) \& 3268 (enacted in I855) ; N. M. Stat. AnN. (Courtright, I929) $\$ \$ 76-101$ (enacted I882); N. Y. Civ. Pract. ACT (I928) §2IIa; N. C. Code ANN. (I93I) \$6I8 (enacted in I929); TEXAS Rev. CIV. Code (Vernon, I928) \$22I2 (enacted I9I7); VA. CODE ANN. (Michie, r930) \$ 5779 (first written into enacted code of I9I9, to clarify law); W. VA. CoDE (I93I) c. 55, art. 7, § I3 (enacted 1873 ). A chief difficulty with most of these enactments is that they permit contribution only between tortfeasors against whom joint judgment has been rendered. See statutes of Maryland, Missouri, New Mexico, New York, Texas, and West Virginia, supra. And these statutes have not changed the well settled common law rule that one injured by joint tortfeasors may sue any or all of them, severally or jointly, as he pleases. See (1930) 39 Y ALE L. J. 909; (I93I) I6 CoRN. L. Q. 246. The result obviously is that these statutes allow contribution only between those of the joint tortfeasors, if any, whom the injured person has in his own untrammeled discretion chosen to sue jointly. The reasons for allowing contribution apply just as strongly to the other cases as to these. Texas has permitted a joint tortfeasor sued singly to implead the others, thus bringing his case within the contribution statute. Lottman v. Cuilla, 288 S. W. I23 (Tex. Com. App., I926), noted in (I928) 6 TEX. L. REv. 554. Under a separate interpleader statute, intermediate New York courts have held both ways, but the Court of Appeals, in Fox v. Western N. Y. Motor Lines, 257 N. Y. 305, I78 N. E. 289 (I931), concluded that the two statutes did not go far enough to create this new right to implead. See also Ward v. Iroquois Gas Corp., $258 \mathrm{~N}$. Y. I24, I79 N. E. 317 (1932). And see Note (1932) 32 Cor. L. REv. 94. The Kentucky, North Carolina, and Virginia statutes apparently allow contribution regardless of the nature of the 
that most of these statutes were drawn hurriedly, and the absence of express reference in them to many of the problems bound to arise under them has caused considerable difficulty in their application. Such defects can easily be eliminated in future enactments. A statute undertaking to avoid them is suggested herewith. An alternative first section defining the area within which contribution is to be allowed is presented.

Section I. Contribution between tortfeasors shall be permitted in all cases where there is joint liability for a tort, whether such tort was intended or unintended by the tortfeasors, the result of concerted or unconcerted action by them, successive or concurrent in time, or otherwise, except that this section shall not apply to cases in which by law one of them is entitled to indemnity against the other.

Alternative Section I. Contribution between tortfeasors shall be permitted in all cases where there is joint liability for a tort, whether such tort was the result of concerted or unconcerted action by the tortfeasors, successive or concurrent in time, or otherwise, except that the right to contribution shall not exist in favor of a tortfeasor who in committing the tortious act intended to commit a tort. This section shall not apply to cases in which by law one of the tortfeasors is entitled to indemnity against the other.

Section 2. Contribution between tortfeasors may be enforced in any action brought against them for the tort, and if any tortfeasor subject to a liability for contribution is not a party to such action he may be impleaded and made a party thereto on the complaint of the party or parties who may have a claim for contribution against him. Such tortfeasors claiming contribution against each other shall be treated

injured person's judgment, the North Carolina enactment being clearest on this point. Another uncertainty in several of the statutes arises from the fact that they would seem to allow contribution between all tortfeasors, even those guilty of intentional wrongdoing. See statutes of Maryland, Missouri, New Mexico, New York, North Carolina, Texas and West Virginia, supra. It has been suggested that these statutes might nevertheless be interpreted as applicable only to negligent or unintended wrongs, (I93I) I6 CoRN. L. Q. 246; though it is difficult to discover any good reason for such limited interpretation. Two of the statutes, those of Kentucky and Virginia, expressly limit the right of contribution to cases "where the wrong is a mere act of negligence, and involves no moral turpitude", terminology open to widely varying interpretations. It is altogether clear that these statutes would be more useful if drawn only after careful consideration of the problems which will arise under them.

The other three states in which contribution is achieved by statute are Kansas, Michigan and Georgia. In Kansas, the result was reached under a procedural statute (KAN. Rev. Stat. ANN. (Ig23) $\$ 60-3437$ ) permitting one judgment debtor paying more than his share of a joint judgment to enforce contribution from the other judgment debtors. City of Fort Scott v. Kansas City, F. S. \& M. R. Co., 66 Kan. 6ro, 72 Pac. 238 (I903). Several other states have similar statutes, but none of them have been held to have the substantive effect of changing the common law rule of no contribution between tortfeasors. For a typical holding, see Forsythe v. Los Angeles Ry. Co., supra note 46 . The Michigan statute (MICH. CoMp. LAws (1929) § I4497; enacted in I9II) for some odd reason permits contribution in libel cases only. It appears to be one of the all-too-frequent instances of a legislator writing a statute to fit one particular case, wholly regardless of the general problem involved. And the Georgia statute (GA. CODE ANN. (Michie, 1926) \$\$ 4512-13; enacted in I86r code) applies only to "joint trespassers". That the term "trespassers" does not include all "tortfeasors", as it might, seems settled in Georgia. See McCalla v. Shaw, $72 \mathrm{Ga} .458$ ( 1884 ) ; Central of Ga. Ry. Co. v. Swift \& Co., supra note 46.

A good review of all the contribution statutes here discussed appears in Note (r93I) 45 HARv. I. REv. 369. 
as adverse parties in the action, with the right to appeal against each other and all other procedural rights allowed by law to adverse parties in actions, save that the controversy between the tortfeasors shall not delay a judgment to which the party suing for the tort is entitled, nor execution thereupon, unless the court otherwise directs. If the claim to contribution be not adjudicated in such first action, any tortfeasor who either after judgment or on voluntary settlement has paid more than his pro rata share of damages for the tort may enforce his claim to contribution by a separate action. The pro rata share of each tortfeasor shall be ascertained by dividing the total of damages properly collected on account of the tort by the number of tortfeasors jointly liable for the tort, and this pro rata share shall be the whole amount to which any tortfeasors shall be entitled as contribution from any other tortfeasor.

In most jurisdictions enactments such as this represent practically the only available hope for getting rid of the no contribution rule, inasmuch as repeated decisions have intrenched it so firmly that it cannot readily be dislodged even by the most courageous and intelligent courts. In the jurisdictions in which the issue remains open, it is possible that the courts will forestall any necessity for legislative action by following the lead of Wisconsin, Pennsylvania, and Minnesota in outright rejection of what appears to be a thoroughly unfortunate and valueless rule of law. Contribution should at least be allowed between tortfeasors who did not intend that their misconduct should produce harmful consequences.

\section{Indemnity}

The idea of indemnity ${ }^{67}$ implies a primary or basic liability in one person, though a second person is also for some reason liable with the first, or even without the first, to a third person. Discharge of the obligation by the second person leaves him with a right to secure compensation from the one who, as between themselves, is primarily liable. The right to indemnity may arise from a contract, as in the case of casualty insurance, or warranty of the quality of goods sold and their fitness for some proposed use to be made of them, or agreement to hold harmless one who contemplates a given course of action, or the like. With such cases of contract for indemnity we are not now concerned. Other types of the right to indemnity are commonly called quasi contractual, or arising out of a "contract implied by law". Indemnity between persons liable for a tort falls within this type of case. As between such persons, the obligation to indemnify is not a

on There is a very close connection between the legal rules as to contribution between tortfeasors, and indemnity between them, but this very fact has often led to a confusing failure to distinguish between the two. In this article, an attempt has been made to avoid that confusion by discussing the problem of contribution without reference to that of indernnity, the relationship between the two problems being brought out in the latter part of the paper, which deals primarily with indemnity. 
consensual one; it is based altogether upon the law's notion-influenced by an equitable background-of what is fair and proper between the parties. It is true that the relationship of the parties, which often affords the decisive clue as to what is fair between them, may have arisen by contract, though it need not have. But in these cases the contract does not create the right to indemnity. It only creates a part of the fact situation, and it is the fact situation in its entirety, consensual and non-consensual elements both included, which gives rise to the obligation to indemnify. The quasi contractual idea of unjust enrichment of course underlies any holding that one who has been compelled in discharging his own legal obligation to pay off a claim which in fairness and good conscience should be paid by another can secure reimbursement from that other. ${ }^{68}$ But in tort indemnity cases, the leading facts are apt to be acts and relationships out of which tort liabilities have arisen, and it will often follow from this that the question of unjust enrichment involved in the granting of indemnity will have to be decided on substantially the same principles as those which controlled the creation of the original tort liability.

In the law of torts the clearest situation for indemnity is that in which the improper act of one person produces injury, and the law permits the injured person to recover for his injury from someone other than the actor. In such case the actor, or possibly someone standing in his stead, must indemnify the one who has been held liable without fault, and by operation of law only, for the actor's misconduct. This brings into close contact, and at the same time into sharp contrast, two leading principles in the law of torts-that of liability for fault alone, and that of absolute liability, or liability without fault. Much of the law of torts is built around an idea of fault. One who is guilty of injurious misconduct, either intentional or negligent, is liable therefor. Of course there are cases of recognizable misconduct causing harm to others for which the law has provided no remedy, but those cases do not affect the immediate point. The idea is that liability in tort cases follows directly from bad conduct. But along with this idea grew up doctrines such as that of respondeat superior and that represented by the rule in Rylands $v$. Fletcher, ${ }^{69}$ doctrines wholly inconsistent with the idea of liability for fault alone, and sometimes bitterly opposed for that reason. ${ }^{70}$ Explanations of respondeat superior designed to show that it was in keeping with standard ideas of liability for fault were attempted. These explanations may or may not have influenced courts in

* Keener, Quast Contracts 408; Woodward, Quasi Contracts 396, 409.

- Supra note 59.

70 See, e. g., BATY, Vicarious LIABIIITy (I916) 146-154. For a short summary of attitudes on the problem, see Pound, Introduction to the Philosophy of Law (Ig2a) I66. 
their acceptance of the doctrine-we do not know. But we do know that such explanations were artificial, that they do not describe what actually happens when respondeat superior is applied, and that the fact of what does actually happen when the doctrine is applied has been sufficient to induce its retention and growth as a part of the law, regardless of explanations. The doctrine of respondeat superior and its fellow doctrines, both statutory and common law, imposing liability irrespective of fault, have operated as a sort of social insurance, lifting the burden of loss off the innocent individual upon whom it happened to fall, and shifting it onto another innocent person who normally has some opportunity to spread it over a portion of society as a whole by adding it to the total cost of production or risk of ownership in the area of social activity out of which the injury arose. Of course there are many individual cases in which this spreading of the loss is impossible, but usually that will mean that the benefit of the activity out of which the injury arose is not one which inures to a considerable social group, but rather solely to the innocent person forced to pay. In either case, the one sponsoring the activity must bear the loss arising out of it, rather than leave the loss on an innocent person unconnected with the activity. At least the former is usually in a better position to pass on the loss to those who may fairly be called on to bear it than is the latter of the two innocents.

Obviously, any doctrine that shifts loss to an innocent person is going to be regarded as a harsh doctrine, one not to be unduly extended. That has been true. Furthermore, the harshness will be minimized as far as possible by such secondary relief as other relevant rules of law can afford. This is the point at which the contact between liability without fault and liability for fault occurs. One whom the law holds to an absolute liability for the wrongful act of another has been injured just as really, even though indirectly, by that wrongful act as though his property had been struck by the other's automobile in the first place. Even though we may properly refer to the right to indemnity in such circumstances as a quasi contractual right based upon unjust enrichment, it is actually supported by simple, fundamental tort law principles just as clearly as is the right to recover for injuries caused directly by the tortious act. Such indemnity is an imposition of liability for fault, and as such is designed to minimize the harshness of previously imposed liability without fault.

Not much space need be spent in listing cases in which one held liable without personal fault for a tortious act can recover indemnity from the real tortfeasor. One held by respondeat superior for the torts of his agent or servant can get indemnity from the latter. ${ }^{71}$ On its face the situation

${ }^{n}$ Smith v. Foran, 43 Conn. 244 (1875); Georgia, So. \& Fla. Ry. v. Jossey, 105 Ga. 27r, 3I S. E. I79 (I898); Costa v. Yoachim, I04 La. I70, 28 So. 992 (I900) ; Grand Trunk Ry. Co. v. Latham, 63 Me. I77 (1874); Hill v. Murphy, 2I2 Mass. I, 98 N. E. 78I (IgI2); 
created by a Workmen's Compensation statute is similar. An employer required to compensate a servant for an injury caused by a third person would seem to have a right to indemnity against the third person. But it has been held that the right given to a workman by a Compensation Act is not in lieu of his tort right against third persons, but additional thereto, leaving the whole right against the third person to the injured workman, and subrogating the employer to none of it. ${ }^{72}$ More recent decisions, however, have been controlled either expressly or impliedly by a right to such subrogation arising from the compensation statute itself. ${ }^{73}$ Insofar as this right is one created by the statutes, cases enforcing it shed no light on the present problem. Situations which are in point, however, include that in which an initial carrier has been held liable to the shipper for the loss of goods shipped but is permitted indemnity against the connecting carrier whose negligence actually caused the loss, ${ }^{74}$ or in which a carrier thus held liable can recover over from the one whose negligence produced the defective condition in the carrier's equipment which caused the injury to the goods, ${ }^{75}$ and that in which an employer held for an injury to an employee on the theory of violation of the non-delegable common law duty to furnish a safe place to work can have indemnity from the one whose negligence rendered the working conditions unsafe. ${ }^{76}$ Perhaps the most common cases of all those coming under this head are the ones in which a municipal cor-

Fedden v. Brooklyn Eastern Dist. Terminal, 204 App. Div. 74I, I99 N. Y. Supp. 9 (I923); Gaffner v. Johnson, 39 Wash. 437, 8 I Pac. 859 (rgo5). And see Ohio Valley Bk. v. Greenebaum Sons Bk. \& Tr. Co., II F. (2d) 87 (C. C. A. 4th, 1926). It is obvious that on similar facts the servant can get neither contribution nor indemnity from the employer. Rumpf v. Callo, I6 I. A. App. I2, I32 So. 763 (I93I). And see Tomerlin v. Krause, 278 S. W. 50I (Tex. Civ. App. I926).

Interstate T. \& T. Co. v. Public Service Elec. Co., 86 N. J. L. 26, 90 At1. 1062 (I914). And see (Igr8) I8 CoL. L. R. 598. This rule was supposed to be in keeping with the rule in life and accident insurance cases that the insurer is not subrogated to rights of the insured or his estate against third persons causing death or injury of the insured. Such subrogation is permitted in property and indemnity insurance cases. See VANCE, INSURANCE (2d ed. 1930) 668. The Workmen's Compensation situation seems different from that in life insurance cases in that by the former there is a statutorily imposed absolute liability on the employer to indemnify for injuries, whereas life insurance is by voluntary contract representing more of investment than of indemnity. Incidentally, it might well be argued that accident insurance has more of the indemnity features of property insurance than of the investment features of life insurance, and that subrogation should be permitted as to it also.

'3 See I Schnetder, WorkMen's Conpensation LaW (I92I) igi-202; Bradbury, WorkMEN's CoMpeNsation (3d ed. rgif) II86-92; HILl \& WILSON, WORKMEN's COMIPENSATION STATUTE LAW (I923) \& xii (summarizing all state statutes). Recent holdings are listed in Notes (1922) 19 A. L. R. 766; (I923) 27 A. L. R. 493; (1925) 37 A. L. R. 838; (I925) 37 A. L. R. 853; (I930) 67 A. L. R. 249 .

'7 Produce Trad. Co. v. Norfolk S. R. R. Co., 178 N. C. 175, 100 S. E. 316 (1919); Texas \& P. Ry. Co. v. Eastin \& Knox, 100 Tex. 556, 102 S. W. 105 (I907).

${ }_{\pi}$ Bethlehem Shipbldg. Co. v. J. Gutradt Co., ro F. (2d) 769 (C. C. A. gth, 1926).

${ }^{7}$ Appalachian Corp. v. Brooklyn Cooperage Co., i5I La. 4I, 9I So. 539 (I922). And see Standard Oil Co. v. Robins Dry Dock \& Rep. Co., 32 F. (2d) I82 (C. C. A. 2d, I929); Mallory S. S. Co. v. Druhan, I7 Ala. App. 365, 84 So. 874 (1920); Busch \& Iatta Painting Co. v. Woermann Constr. Co., 310 Mo. 4I9, 276 S. W. 6I4 (I925). It should be noted that in many of these cases negligence is attributable to the employer, from his failure to discover and remedy the unsafe condition. The cases will be discussed from that point of view later in this article. 
poration is held liable to a person injured by defects in a highway, sidewalk, or other product of municipal activity for public use, and is then allowed to secure reimbursement from the parties who created the defect. ${ }^{77}$ Almost identical with the municipal corporation cases are those in which an occupier of premises is held liable for injuries arising from dangerous conditions thereon, but can recover over from the one who unknown to him created the dangerous condition, ${ }^{78}$ and those in which the owner of leased premises is held to the same liability, but can recover over from the lessee in possession. ${ }^{79}$ Various other situations could be recalled in which one held liable without fault by operation of law can recover over from the one whose fault actually produced the injury, ${ }^{80}$ but enough have been given to illustrate the principle adequately, and to point out the direction of its application and growth. This sort of liability regardless of personal fault seems to be extending itself in our law, both through legislative enactment and judicial decision, and as it extends itself there will tend to be an equivalent extension of rights to indemnity, arising from an attempt to allocate ultimate loss according to more orthodox principles of tort law, principles which will still be alive and active despite the attempt to distribute immediate losses quickly on some more socialized theory.

II

Very closely related to the absolute liability cases just dealt with is another, smaller group of cases, in which it is held that one voluntarily but innocently and in good faith doing at the direction of another person an act which on its face appears lawful and proper, but which is in fact tortious, will be given indemnity against the one causing him to do the act. A typical situation occurs when a creditor or his attorney directs a peace officer

T7 Fort Scott v. Penn Lubric Oil Co., I22 Kan. 369, 252 Pac. 268 (1927); Chesapeake \& Ohio Canal Co. v. Allegheny County, $57 \mathrm{Md}$. 20I (I88I); Township of Hart v. Noret, I9I Mich. 427, I58 N. W. If (I916). And see Washington Gaslight Co. v. District of Columbia, I6I U.S. 316 , I6 Sup. Ct. 564 (I896); 4 Dillon, Municipal Corporations (5th ed. IgII) 3032. Frequently, also, the municipal corporation is itself deemed guilty of negligence, from its failure to discover and remedy the defect. Such cases will be discussed later in this paper.

${ }^{73}$ Westfield Gas \& Mill. Co. v. Noblesville \& E. Gravel Rd. Co., I3 Ind. App. 48I, 4I N. E. 955 (I895); Gray v. Boston Gas Light Co., II4 Mass. I49 (1873); Churchill v. Holt, I27 Mass. I65 (I879). And see Ga. Power Co. v. Banning Cotton Mills, 42 Ga. App. $67 \mathrm{r}$, 157 S. E. 525 (193I).

T9 Oceanic Steam Nav. Co. v. Compania Transatlantica Espanola, I34 N. Y. 46r, 31 N. E. 98; (I892), And see Miller v. New York Oil Co., 34 Wyo. 272, 243 Pac. II8 (1926). Many of the lessor-lessee cases involve express agreements by the lessee to maintain repairs and hold the lessor harmless for failure to do so. In such cases, the covenant being a valid one and not against public policy, it controls as a contract, and quasi contract or tort principles are not relevant. See Trego v. Rubovitz, I78 Ill. App. I27 (Ig13) ; Commercial Cas. Ins. Co. v. Capital City Surety Co., 224 App. Div. 553, 23I N. Y. Supp. 494 (1928).

${ }_{80}^{80}$ See Sutton v. Champagne, I4I La. 469,75 So. 209 (I9I7), in which plaintiff who had been held under a statute making a parent liable for the torts of his minor child was given indemnity against one whose negligence was the proximate cause of the child's commission of the tort. For summary of cases see Notes (Igr2) 40 L. R. A. (N. S.) II47, II53, II65, II72. 
to levy an attachment upon certain goods as those of a debtor, the goods are in fact not subject to the levy, and the officer is compelled to pay damages for the wrongful attachment. The officer can recover over from the one directing him to levy the attachment. ${ }^{81}$ The same is true if an agent is thus induced to convert the goods of another by any other acts, ${ }^{82}$ or to trespass upon realty, ${ }^{83}$ or to commit any other tort whatever. ${ }^{84}$ The right to indemnity exists even though the one directing the act to be done be as innocent as the actor ${ }^{85}$ on the theory that, as between the two, the one ordering the act done, presumably for his own benefit, should take the responsibility for its legality. This theory often induces courts to talk about an "implied contract" to indemnify under such circumstances, ${ }^{86}$ but the relief is actually given entirely apart from any discoverable contract. Of course, there often will be an express contract to indemnify the one doing the act; in such case the right is measured by the contract, ${ }^{87}$ assuming the contract to be a valid one not against public policy, and the results are not particularly helpful in a study of non-contractual indemnity.

\section{III}

Another group of cases in which indemnity is allowed has its origin in what is known as the last clear chance doctrine, an aspect of the law of contributory negligence. What is meant by the doctrine of the last clear chance, ${ }^{88}$ sometimes called the doctrine of discovered peril, is well enough known; it is to the effect that if a plaintiff guilty of contributory negligence is harmed by a negligent defendant, the plaintiff can still recover for the injury if as between the two the defendant had the "last clear chance" to prevent it. In some jurisdictions this last clear chance must have been one perceived by the defendant in time for him to prevent the injury, else the

sa Higgins v. Russo, 72 Conn. 238, 43 At1. I050 (1899); Selz, Schwab \& Co. v. Guthman, supra note 43 ; Gower y. Emery, I8 Me. 79 (I84I).

${ }^{2}$ Adamson v. Jarvis, 4 Bing. 66 (C. P. I827); Betts v. Gibbons, 2 A. \& E. 57 (K. B. 1834) ; Hoggan v. Cahoon, 26 Utah 444, 73 Pac. 512 (1903).

Horrabin v. Des Moines, I98 Iowa 549 , 199 N. W. 988 (1924).

s Howe v. Buffalo, N. Y. \& E. RR. Co., 37 N. Y. 297 (I867) (wrongful expulsion of railway passenger by conductor); Culmer v. Wilson, I3 Utah I29, 44 Pac. 833 (I896) (wrongful institution of legal proceedings). See also STORY, AGENCY (9th ed. I88I) § 339; MECHEN, OUTLINES op AGENCY (3d ed. I923) 269. It should be borne in mind, however, that if the one doing the act goes beyond his instructions in doing it, so that he may be said to have acted on his own initiative, he will have no claim to indemnity. Nelson $v$. Cook, I7 IIl. 443 (I856); Russell v. Walker, I50 Mass. 531, 23 N. E. 383 (I890). The CAL. CIV. CODE (Deering, I923) \$ 1969, provides that an employer directing his servant to do an unlawful act must indemnify him for liabilities therefor, unless the servant at the time of obeying the directions believed them to be unlawful. The same provision appears in N. D. COMP. LAWS ANN. (I913) \&6106 and S. D. CoMp. LAwS (I929) \& 1072.

$\therefore$ Culmer v. Wilson, supra note 84 ; MECHEM, loc. cit. supra note 84 .

so Sheffeld Corp. v. Barclay, [Ig05] A. C. 392; Higgins v. Russo, supra note 81. Cf. Atkins v. Johnson, 43 Vt. 78 (1870). I836).

g7 Coventry v. Barton, I7 Johns. I42 (N. Y. I819); Davis v. Arledge, 3 Hill I70 (S. C.

Throcknorton's Cooley on Torts 648; Clerk \& Lindseid, Torts 457; Salarond, Torts 4I. See Bohlen, The Rule in British Columbia Ry. Co. v. Loach (IgI7) 66 U. or PA. L. Ret. 73; Note (1932) 32 CoL. L. REV. 493. 
ordinary rule of contributory negligence will bar the plaintiff from relief; in other jurisdictions it is enough that the defendant did have the last clear chance and should have known that he had it. There are some jurisdictions which do not accept the last clear chance doctrine at all, and there are others which go beyond it, applying what is called a "humanitarian doctrine" the effect of which is to shift the whole loss in almost every case of certain types, regardless of contributory negligence. For present purposes it is enough to assume that the doctrine is accepted as law in whatever form happens to be agreeable to the particular jurisdiction.

The indemnity situation arising from the last clear chance rule is fairly presented by the leading case, Nashua Iron \& Steel Co. v. Worcester $\mathcal{E} N . R . R . \mathrm{Co}^{89}$ The declaration set out that due to defendant's negligence the plaintiff's horse was frightened, and ran over and injured one Clapp, who sued the plaintiffs, recovering judgment and satisfaction thereof, wherefore plaintiffs asked indemnity. Defendant demurred. The court assumed facts possible under the declaration, to wit, that though plaintiffs negligently mismanaged the horse defendant had, and plaintiffs had not, a later chance, by the use of due care, to avoid frightening it. The doctrine of the last clear chance was accepted. The court said "O "One who is so far innocent that he can recover for an injury to his person or property, may also recover whatever sum he, by reason of his relation to the wrong, has been compelled to pay a third person. If the plaintiffs could recover for an injury to their horse caused by the accident, they may recover the sum which they paid to Clapp." In other words, the indemnity case is treated exactly the same way that a torts case would be treated; it is treated as a torts case, even though the theory of recovery is necessarily that of unjust enrichment. If the set of facts is one to which the last clear chance doctrine is applicable, it makes no difference whether the plaintiff's injury was to his person, his horse, or his pocketbook-his right to recover is measured by the same standard. It is submitted that this is as it should be. ${ }^{91}$ It needs no argument to show that the facts in the New Hampshire case just stated are virtually the same as those in Davies $v$. Mann. ${ }^{22}$ No reason of policy has ever been brought forward to differentiate the two, and the only difference of any kind between them is that in the indemnity case the area of the plaintiff's loss, for which he seeks recovery, has been a little greater. It is

${ }^{60} 62$ N. H. I59 (I882).

${ }^{\infty}$ At 160 .

${ }^{91}$ Professor Bohlen many years ago took the opposite attitude, referring to the New Hampshire case as a "sheer anomaly". Bohlen, Contributory Negligence (Igo8) 21 HARv. L. REv. 233 at $242-3$. It should be noted, however, that his article does not purport to analyze the whole group of contribution and indemnity cases. It altogether fails to recognize the similarity in operation of the contributory negligence rule and the no contribution rule in negligence cases.

${ }^{2} 10$ M. \& W. 546 (Ex. I842), the famous Donkey Case generally credited with giving rise to the doctrine of the last clear chance. 
almost as though defendant had run down two of plaintiff's donkeys instead of one. The difference in total loss for which the plaintiff seeks recovery, and the fact that the loss took two forms instead of one, seem altogether unimportant distinctions between the cases, so long as the causative factors active in producing the loss were substantially similar. ${ }^{93}$

Not many cases have arisen in which this precise point as to the right to indemnity was raised. In no discovered case in which the point was raised has the right been rejected, and there have been other cases in which it was explicitly accepted. ${ }^{94}$ There is another group of cases, however, in which the same results have been reached on similar facts, though with different language used in the opinions. A fair sample of these cases is Austin Elec. Ry. Co. v. Faust, ${ }^{95}$ in which a street car had collided with a horse-drawn ice wagon, causing the team to run away and injure a third party, who recovered a joint judgment against the street car company and the ice company. The ice company claimed indemnity from the street car company, basing its claim on evidence that the street car operator could have stopped his car after he saw that the wagon was in a dangerous position from which it could not escape. The court overruled the street car company's demurrer, saying "But as to the two negligent parties, if the negligence of one was merely passive, or was such as only to produce the occasion, and the other negligent party was the active perpetrator of the wrong, the former may recover over against the latter." So in City of Weatherford Water, Light \& Ice Co. v. Veit, ${ }^{96}$ an electric company's wire was negligently allowed to remain uninsulated on a pole very close to which a telephone company with knowledge of the condition of the electric wire put up a pole and wires. The telephone company's negligence in failing to give warning of the danger to one of its employees sent by it to work on its pole was held by the court to be active negligence, as distinguished from the

${ }^{*}$ Cf. Shield v. Johnson \& Son Co., I32 La. 773, 61 So. 787 (I913), saying "The doctrine of last clear chance cannot be invoked by joint tortfeasors against each other. It has been applied only in those cases in which the injured party has been negligent in exposing himself to peril." The same general language is to be found in a number of other cases. See Pacific Tel. \& T. Co. v. Parmenter, I70 Fed. I40 (C. C. A. gth, Ig09); Cordiner v. Los Angeles Trac. Co., 5 Cal. App. 400, 91 Pac. 436 (I907); Bradley v. Becker, 32I Mo. 405, II S. W. (2d) 8 (I928). But in none of the cases making such statements was any question of indemnity involved; in all of them the statement arose out of attempts between joint tortfeasor defendants to limit the injured plaintiff's right to an action against the one of the defendants who had a last clear chance to prevent the injury. And all the court decided in any of these cases was that the plaintiff's right was complete against the tortfeasors jointly and severally, and that they would have to settle their own dispute in a separate action between themselves. At no time did a court say, nor would it have been appropriate on the issues for it to say, that no such separate action between the defendants could later be brought.

Colorado \& So. Ry. Co. v. Western Light \& Power Co., 73 Colo. I07, 214 Pac. 30 (1923), is the clearest case. Colonial Motor Coach Corp. v. New York C. R. R. Co., I3I Misc. \&9I, 228 N. Y. Supp. 508 (I928), and Knippenberg v. Lord \& Taylor, 193 App. Div. $753,184 \mathrm{~N}$. Y. Supp. 785 (1920), contain strong dicta.

${ }^{\circ 6} 63$ Tex. Civ. App. 91, I33 S. W. 449 (I9II).

$\$ 196$ S. W. 986 (Tex. Civ. App. 1917). See also Southwestern Tel. \& T. Co. v. Krause, 92 S. W. 431 (Tex. Civ. App. 1906). 
electric company's passive negligence in maintaining the uninsulated wire, so that the electric company was entitled to indemnity against the telephone company for damages paid to the employee who was injured by contact with the uninsulated wire. In such cases as these, it is obvious that the talk about passive and active negligence is artificial, that the distinction between passivity and activity is a wholly indistinct one, ${ }^{97}$ and that the court is really giving indemnity against the one who had the last clear chance to avoid the injury.

An interesting variation of the last clear chance situation remains to be noticed. It arises out of the well known principle of proximate causation, that one causing a physical injury to another will be liable not only for the immediate injury but also for the results of negligent treatment of the injury by a physician selected with reasonable care. ${ }^{98}$ The point to be considered is as to whether the one causing the original injury can in turn recover from the negligent physician the amount by which his negligence increased the former's liability. It has been held that such recovery over is permissible. ${ }^{99}$ In a sense, the rule of proximate causation just alluded to is one imposing liability regardless of fault, and in that sense the grant of indemnity lines up with that in the first group of cases discussed in the latter half of this paper. It is improbable, though, that any rule of proximate causation, imposing liability for the consequences of negligent or intentional wrongdoing, can be referred to as imposing liability without fault, however far the consequences may be removed from the original wrongdoing. The right to indemnity can as well be supported on the theory that the negligent intervener had the last opportunity to prevent the aggravation of the injury. Under either theory the result seems eminently desirable.

\section{IV}

The three fields of tort indemnity so far dealt with are all fairly well formulated in the cases, definitely and expressly in the language herein used. There remains, however, a considerable body of cases in which indemnity is granted to one who has been held liable in tort for his own negligence in failing to discover and remedy a dangerous condition created by the negligence or wrongful act of the one against whom indemnity is given. It has been pointed out that in these cases such last clear chance as there may have

" A striking example of this artificiality occurs in Eastern Texas Elec. Co. v. Joiner, 27 S. W. (2d) gI7 (Tex. Civ. App. 1930). There had been a collision between a street car and a truck, injuring a third person. The court said "The operator of the street car was guilty of negligence in failing to sound the bell before entering the street intersection and in stopping the street car in the street intersection and in failing to keep a lookout for vehicles in approaching the street intersection and in failing to stop the street car immediately before entering the intersection. These acts of negligence were merely passive ..." The court then referred to the truck driver's negligence in ramming the street car as active, and held the street car company therefore entitled to indemnity from the truck owner. At 918 .

${ }_{8}$ For collection of cases, see Note (I914) 48 L. R. A. (N. s.) II6.

${ }^{\circ}$ Fisher v. Milwaukee Elec. Ry. \& Light Co., 173 Wis. 57, 180 N. W. 269 (1920). 
been on the facts was generally in the one to whom indemnity was awarded.100 The reasons given by courts in deciding this body of cases are various and uncertain; no clear cogent analysis and classification of them has ever been fixed on. Sometimes, in municipal corporations cases particularly, courts will first hold that an injured person can recover from both or either of two parties, on the ground that one negligently created a dangerous condition and that the other negligently failed to discover and remedy it, and then pass on to say that the second can have indemnity from the first on the ground, among others, that he is liable only by inference of law for, and not as a participant in, the active misconduct of the first. Such reasoning of course is contradictory, and in no sense helpful. Most of the cases rely on the idea that the one receiving indemnity was guilty of passive negligence only while the other was guilty of active negligence, or on the idea that he was not in pari delicto with the other, or on both ideas. While these ideas at least suggest intelligible reasons for allowing indemnity in some cases, they are not very useful in selecting the particular cases in which indemnity is to be allowed, because they lay down no definite standards or rules for analysis of cases. And any attempt to get aid by analogies drawn from contributory negligence must fail, for here there has been definite development beyond the limits of that doctrine.

The uncertainty and unreality of a distinction between active and passive negligence as a test of the right to indemnity has already been pointed out in the last clear chance cases. ${ }^{101}$ In those cases the so-called passive negligence came first and the active negligence later. In the remaining cases which rely upon this language as a basis for granting indemnity 102 the active negligence came first and the passive negligence came later, taking the form of failure to discover and remedy the dangerous situation created by the active negligence. The distinction between misfeasance and nonfeasance may furnish a fairly good description of the cases, or of some of them, and it is not to be denied that it is a fundamental sort of distinction which is at the bottom of a great deal of the common law of torts. ${ }^{103}$ But it is not a clear distinction; misfeasance and nonfeasance shade into each other, and in many cases a given set of facts can with a little ingenuity be described as either the one or the other, at the describer's

${ }^{100}$ Bohlen, supra note 9I, at 243.

Im Sipra notes $95,96,97$.

${ }^{102}$ For typical cases, see Standard Oil Co. v. Robins Dry Dock \& Rep. Co., supra note 76; South Western Bell Tel. Co. v. Eastern Texas Publ. Service Co., 48 F. (2d) 23 (C. C. A 5 (h, I93I) ; Central of Ga. Ry. Co. v. Macon Ry. \& It. Co., I40 Ga. 309, 78 S. E. 93 I (1913); Pullman Co. v. Cincinnati, N. O. \& T. P. R. Co., 147 Ky. 498, I44 S. W. 385 (I912); Astoria v. Astoria \& Columbia River Ry. Co.; 67 Ore. 538, I36 Pac. 645 (I9I3) ; East Texas Public Service Co. v. Johnson, 6 S. W. (2d) 344 (Tex. Com. App. I928). Cf. Portland v. Citizens Tel. Co., 206 Mich. 632, 173 N. W. 382 (1919), in which indemnity was refused, because both parties deemed active, neither passive.

${ }_{103}$ See Bohlen, Moral Duty to Aid Others as a Basis of Tort Liability (1908) 56 U. of PA. L. REV. 2I\%, 3 I6. 
will. ${ }^{104}$ The cases in which this passive-active language has been used to explain grants of indemnity are all within one or the other of the two fact situations mentioned at the beginning of this paragraph, whereas other possible instances of joint passive and active negligence, such as cases of concurrent rather than successive negligence, or of failure to remedy an already discovered dangerous condition created by another, ${ }^{105}$ are not generally treated as giving rise to a right to indemnity. The inadequacy of the words "passive" and "active" as a test of the propriety of allowing indemnity in hard cases must be apparent.

The other formula of language, which occurs even more frequently in the decided cases, is to the effect that indemnity will be allowed where the tortfeasors are not in pari delicto. ${ }^{106}$ Here again is an idea which has real meaning, one which has had genuine influence on the shaping of numerous common law rules. It has long served to indicate an area within which the law's unwillingness to concern itself in quarrels between wrongdoers was somewhat slackened. It is valid as a general reason, though a rather vague one, for allowing indemnity in some cases and in others not. Yet it cannot possibly serve and never has served as a complete and accurate measure for the right to indemnity between tortfeasors in the cases as they arise. It is used to support decisions already arrived at. More or less substantial differences in degree of fault could be discovered between tortfeasors in a great many joint liability cases in which the law has never suggested any grant of indemnity to the one least at fault. Complete observance of the dictum that indemnity will be allowed between joint tortfeasors not in pari delicto would carry the common law beyond the farthest point to which comparative negligence has ever gone, and beyond the broadest definitions of the doctrine of the last clear chance. Actually, of course, no such extension has ever been contemplated. The language is used merely in reference to cases within the three general fields of permissible tort indemnity already dealt with, plus the fourth field in which indemnity is given to one whose only negligence was a failure to discover and remedy a dangerous condition formerly created by the misconduct of the one against whom indemnity is given.

There seems no good reason for failing to formulate the rule in the reasonably clear form just indicated. That states what happens in the cases, regardless of the more general language used. It represents what happens

${ }^{204}$ For example, see Eastern Texas Elec. Co. v. Joiner, supra note 97.

${ }^{100}$ See infra note II2.

${ }^{103}$ For typical cases, see Middlesboro Home Tel. Co. v. Louisville \& N. R. R. Co., $2 I_{4}$ Ky. 822, 284 S. W. I04 (1926); Lowell.v. Boston \& L. Ry. Co., 23 Pick. 24 (Mass. I839); Churchill v. Holt, supra note 78; Fidelity \& Cas. Co. of N. Y v. North Western Tel. Exch. Co., 140 Minn. 229, 167 N. W. 800 (1918); Busch \& Latta Painting Co. v. Woermann Constr. Co., supra note 76 . Cf. Larkin Co. v. Terminal Warehouse Co., supra note 46, in which indemnity was refused because parties deemed to be in pari delicto. 
in the municipal corporations cases ${ }^{107}$ as well as in the cases where the contest is between private parties. ${ }^{108}$ That the allowance of indemnity in such cases produces a result fairer than that of leaving the whole burden on the one now given indemnity cannot be denied; as between the two parties the courts have clearly seen the greater responsibility of the one who created the dangerous situation. ${ }^{109}$ This idea has been emphasized by some of the decisions which draw an analogy to implied warranties in the law of sales. These are for the most part cases in which defective and dangerous articles have been furnished by one to another for a particular use, the one furnishing them being required to indemnify the other for damages paid to third persons injured by the articles. ${ }^{110}$ The party receiving indemnity was negligent in his failure to discover the defects, therefore liable to third persons, but the one who furnished the article created the dangerous situation and led the other to believe it was not dangerous. Probably a contract action on implied warranty of fitness, as such, would not be broad enough to cover a right to tort indemnity, but it comes very close to it, and certainly serves by analogy to support the allowance of tort indemnity. ${ }^{111}$ One confusing point remains in this group of cases: If one person creates a dangerous condition, and a second, being under a legal duty to discover and remedy it, discovers it but does not remedy it before a third person is injured, is the second person still entitled to indemnity against the first? The courts have generally treated the tortfeasors as being in pari delicto under these circumstances, and have said that the equality of fault bars indemnity. ${ }^{112}$ In a leading case reaching an apparently opposite result ${ }^{113}$ it seems that the city, which received indemnity from the creator of a dangerous situation,

${ }^{100}$ Washington Gaslight Co. v. District of Columbia, supra note 77; Des Moines v. Des Moines Water Co., I88 Iowa 24 , I75 N. W. 821 (1920); Lowell v. Boston \& I. Ry. Co., supra note 106; Astoria v. Astoria \& C. Ry. Co., supra note 102; and literally hundreds of other cases. See (I9I2) 40 L. R. A. (N. S.) 1165; (I929) 62 A. L. R. 1067; (I93I) 70 A. L. R. $1358,1386$.

${ }^{203}$ See cases cited supra notes 102 and I06.

${ }^{200}$ This does not mean, of course, that a division of the burden between them, by contribution, might not be a still fairer result.

${ }^{110}$ Mowbray v. Merryweather, I Q. B. 857 (1895) ; Mallory S. S. Co. v. Druhan, supra note $7 \sigma$; Boston Rubber Co. v. Kendall, I78 Mass. 232, 59 N. E. 657 (rgor); Busch \& Latta Painting Co. v. Woermann Constr. Co., sipra note 76 ; Wanamaker, Inc. v. Otis Elev. Co., 228 N. Y. I92, I26 N. E. 718 (I920); and see Pfarr, et al. v. Standard Oil Co., I65 Iowa 657,146 N. W. 851 (1914).

ix Of course there may be express contracts, either oral, written, or by bond, to indemnify another against tort liability, either as it may arise out of particular transactions, or generally. These contracts are enforceable as such, unless public policy causes them to be treated as illegal contracts. Eureka Coal Co. v. Louisville \& N. Ry. Co., supra note 45; Griffiths \& Son Co. v. National Fireproofing Co., 310 III. 33I, I4I N. E. 739 (I923) ; Ecuyer v. Benevolent Ass'n of Elks, I52 La. 73, 92 So. 739 (1922). Such, contracts are generally deemed legal unless they are made in direct contemplation of known tortious acts to be intentionally committed. See 3 Wriliston, Contracts § I75I.

${ }^{212}$ Central of Ga. Ry. Co. v. Swift \& Co.; Larkin Co. v. Terminal Warehouse Co.; Cain v. Quannah Lt. \& Ice Co., all supra note 46; Galveston v. Gonzales, 6 Tex. Civ. App. 538, 25 S. W. 978 (1894). And see Nashville v. Singer \& Johnson Fert. Co., I27 Tenn. I07, I53 S. W. 838 (1913).

${ }^{23}$ Chicago City v. Robbins, 2 Black 4 I8 (U. S. I862) ; s. c. 4 Wall. 657 ( U. S. I866). 
had done about all that it could be expected to do toward making things safe when it repeatedly warned the defendant to eliminate the danger. To allow indemnity in cases where one under a legal duty to correct a dangerous situation has done nothing toward that end despite knowledge of all the facts would be to shift the whole burden of loss onto one tortfeasor from another whose improper conduct is fully as odious. Perhaps contribution ought to be allowed on such facts, but the decisions seem quite sound in their denial of entire indemnity. That right should be limited to cases in which the plaintiff's negligence consisted of no more than a failure to discover and remedy a pre-existent dangerous condition created by the defendant.

\section{$\mathrm{V}$}

It must also be remembered that obligations to do acts may be delegated, for example by contract. A city under legal obligation to maintain a public structure in safe condition may contract with an individual to take complete charge of such maintenance. The absence of an express agreement to indemnify the city against liability for unsafe conditions in the structure will not affect the right to such indemnity. The individual's failure to perform his contract obligation amounts to the same thing as the creation of the dangerous condition in the cases dealt with in the last paragraph, and the extent of the right to indemnity is identical. ${ }^{114}$ The same is of course true of such contracts between private persons. ${ }^{115}$ And the situation in which a municipal corporation is by statute or city ordinance enabled to require abutting landowners or others to maintain streets, sidewalks and the like in safe condition is in no respect different from the contract cases; there has been an effective delegation, as between the parties themselves, of the duty to remedy defects. ${ }^{116}$ This does not lessen the rights of the injured person against the municipal corporation, but it does create a right to indemnity in the municipal corporation whose only fault has been a failure to discover and remedy the defect, against the one to whom it has validly delegated the duty. These delegations of duty operate only to extend slightly the area of permissible indemnity outlined in the fourth main group of indemnity cases herein indicated.

${ }^{11}$ Robertson, et al. v. Paducah, I46 Ky. I88, I42 S. W. 370 (I912); Campbell v. Somerville, II4 Mass. 334 (I874); Brooklyn v. Brooklyn City R. Co., 47 N. Y. 475 (I872).

${ }_{115}$ Fuller Co. v. Otis Elev. Co., 245 U. S. 489, 38 Sup. Ct. I80 (I918); Georgia Power Co. v. Banning Cotton Mills, supra note 78; Chicago Rys. Co. v. Conway Co., 219 Ill. App. 220 (1920); Minneapolis Mill Co. v. Wheeler, 31 Minn. 121, I6 N. W. 698 (I883); Boston \& M. R. R. Co. v. Brackett, 7 I N. H. 494, 53 Atl. 304 (I902); New York Consol. Ry. Co. v. Massachusetts Bonding \& Ins. Co., I93 App. Div. 438, I84 N. Y. Supp. 243 (I920); aff'd., 233 N. Y. 547, I35 N. E. 912 (I922), and see Note (1925) 38 A. L. R. 566.

${ }_{200}$ Detroit v. Chaffee, 70 Mich. 80, 37 N. W. 882 (I888); Ashley v. Lehigh \& WilkesBarre Coal Co., $232 \mathrm{~Pa}$. 425, 81 At1. 442 (I9II). There have been some cases contra. See (I908) I2 L. R. A. (N. S.) 949, and cf. (I923) 24 A. L. R. 387. 


\section{Conclusion}

The area within which the law grants indemnity between tortfeasors is not great. There seems to be no particular reason why it should be broadened. Indemnity between tortfeasors serves a good purpose when as between them substantially the whole of the fault was in the one against whom indemnity was given. Roughly, that is the area within which it is now permitted. As between others jointly liable for torts, it is submitted that contribution should be allowed. This result is admittedly inconsistent with the doctrine of contributory negligence and related rules; it causes the law to settle between litigants disputes arising out of their own misconduct. But the reasons given against adjudication of such disputes, at least as between joint tortfeasors, are of doubtful validity, and are completely offset by the social evils which accrue from refusal to adjudicate the disputes. The deciding factor, then, should be fairness as between the parties. That calls for the allowance of contribution. 